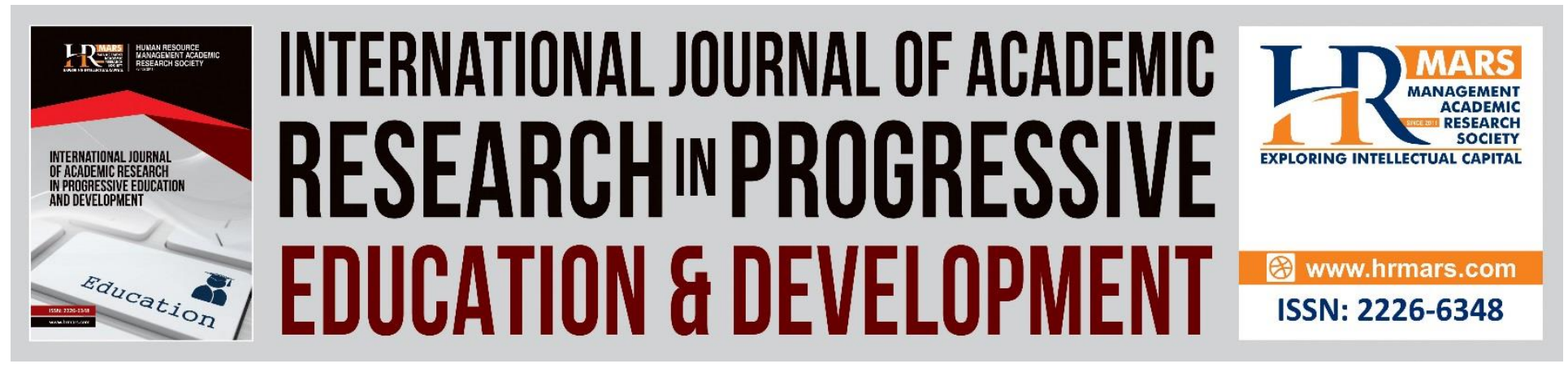

\title{
Barriers to Access the Information by Male Juvenile Delinquents in Malaysia
}

E.R.K. Rafedzi, Nur Khairunnisha Zainal, Halida Yu and J.I.A. Kamal

To Link this Article: http://dx.doi.org/10.6007/IJARPED/v7-i3/4349

DOI: $10.6007 /$ IJARPED/v7-i3/4349

Received: 03 June 2018, Revised: 19 June 2018, Accepted: 05 July 2018

Published Online: 20 July 2018

In-Text Citation: (Rafedzi, Zainal, Yu, \& Kamal, 2018)

To Cite this Article: Rafedzi, E. R. K., Zainal, N. K., Yu, H., \& Kamal, J. I. A. (2018). Barriers to Access the Information by Male Juvenile Delinquents in Malaysia. International Journal of Academic Research in Progressive Education and Development, 7(3), 86-95.

Copyright: (C) 2018 The Author(s)

Published by Human Resource Management Academic Research Society (www.hrmars.com)

This article is published under the Creative Commons Attribution (CC BY 4.0) license. Anyone may reproduce, distribute, translate and create derivative works of this article (for both commercial and non-commercial purposes), subject to full attribution to the original publication and authors. The full terms of this license may be seen

at: http://creativecommons.org/licences/by/4.0/legalcode

Vol. 7, No. 3, July 2018, Pg. 86 - 95

http://hrmars.com/index.php/pages/detail/IJARPED

JOURNAL HOMEPAGE

Full Terms \& Conditions of access and use can be found at http://hrmars.com/index.php/pages/detail/publication-ethics 


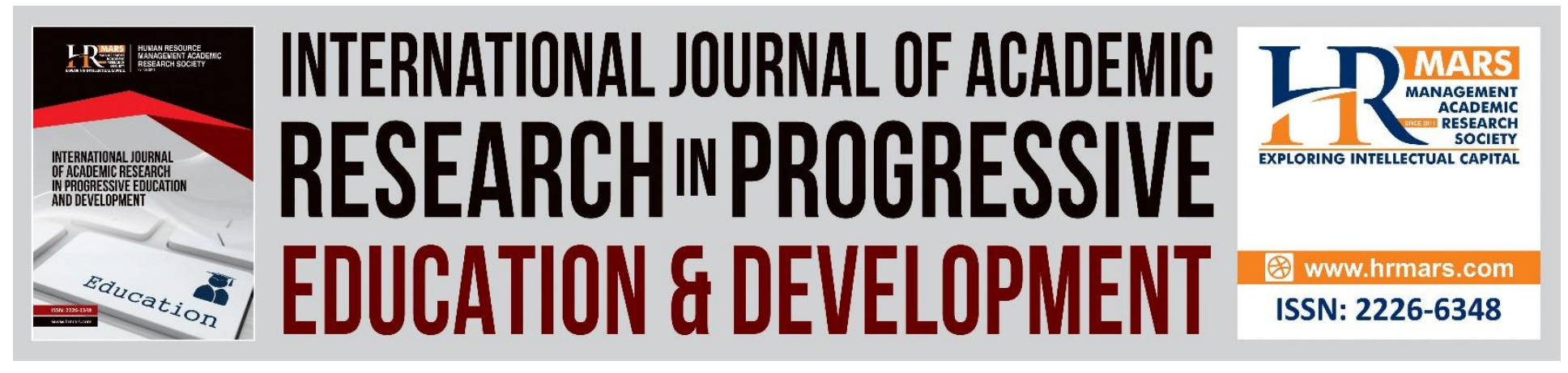

\title{
Barriers to Access the Information by Male Juvenile Delinquents in Malaysia
}

\author{
E.R.K. Rafedzi ${ }^{1}$, Nur Khairunnisha Zainal ${ }^{2}$, Halida $\mathrm{Yu}^{1}$ and J.I.A. \\ Kamal $^{1}$ \\ ${ }^{1}$ Faculty of Information Management \\ Universiti Teknologi Mara, Shah Alam, Selangor, Malaysia \\ ${ }^{2}$ Asia Pasific University \\ Technology Park Bukit Jalil, Kuala Lumpur, Malaysia \\ Email: ezza464@salam.uitm.edu.my (Corresponding Author); \\ nurkhairunnisha@apu.edu.my; halidayu@gmail.com; jannatuliza@gmail.com
}

\begin{abstract}
The study explores how the prison information environment supports the information needs of the male juvenile delinquents in correctional schools in Malaysia. It may be tempting to assume that information seeking failure is inevitable, in a large measure due to the shortcomings on the part of the prison library itself. Apparently, it is not due to the juvenile delinquents' lack of desire to seek for information, but rather, the prison institutions provide inappropriate choices of sources. The study involved twenty six (26) participants living in five (5) correctional schools in Malaysia. Collection of material needs to be upgraded to increase their interest in reading and to appreciate the function and role of the library. The male juvenile delinquents need to be trained to stay alert to the worldwide issues happened outside of prisons as the information can help them when being released at one day.
\end{abstract}

Keywords : Male juvenile delinquents, Prison library, Malaysia, Library Science

\section{Introduction}

Today, juvenile delinquents are no longer focused on small criminal offenses such as stealing or fighting. They were involved in crimes such as murder, gangstarisme, kidnapping, robbery, rape and drug cases (Rafedzi \& Abrizah, 2016). According to Jabatan Perangkaan Malaysia (Department of Statistic Malaysia, 2016), the number of juvenile delinquents decreased by 10.3 percent from 5,096 cases in 2014 to 4,569 cases in 2015. However, repeated offenses recorded an increase of 12.4 per cent of the 371 cases in 2014 to 417 cases in 2015. Surprisingly by the end of the year 2015, a 19 year old militant who joined an Al-Qaeda terror cell in Syria was nabbed at the Kuala Lumpur International Airport (KLIA) (Farik, 2015). According to the news, the teenager; who joined the Al Jund Al-Aqsa cell, was detained by the Bukit Aman special branch counter- 
Vol. 7, No. 3, July 2018, E-ISSN: 2226-6348 @ 2018 HRMARS

terrorism division upon arrival from Turkey on December 2015. The Malaysian police believe that he has undergone weapons training at a few of the cell's training grounds in Hamar and Idlip in Syria. This news has shocked the nation because the offender is a young man; aged 19 years and has been involved in terrorist activity.

The transition from childhood to adulthood is a very complex and confusing for young people. They will be exposed and deceived by things around them. For an example, the abundance of information in the cyber world, digital information and printed material make them thinking and observe without the help or control of an adult. As a result, young people maybe easily influenced by the symptoms of unhealthy information. According to Section 2, the Prisons Act 1995 (Act 537): Prisons regulations 2000 (amendment, 2003); a young prisoner refers to a prisoner under the age of twenty-one years old. Increased numbers of crime incidences among teenagers have caused many young people to waste their time in prison. Based on studies of the Research Institute of Malaysia, in collaboration with the Youth Development Center for Psychology and Development Malaysia; the youths attributed the causes for this problem as follows : $48.1 \%$ said that it was due to their boring lives, $38 \%$ because of their hobbies, and $27.8 \%$ said they were influenced by friends. According to Hassan (2004), $80 \%$ of juveniles involved in crime come from families with incomes of less than RM1000 and have a large number of family members. This create pressure and an uncomfortable situation at home for the juveniles. Therefore, according to Vacca (2008), inmates need education programs which not only teach them how to read efficiently, but also provide the necessary reinforcement that helps to promote a positive transition to the society when they are released.

In the prison environment, after finishing their school education, it is the inmates' choice whether to move further with their education. In Malaysia, normally male juvenile delinquents who are detained for more than 3 years will choose to continue their education. A prison is not a conducive environment for academic learning (Asher, 2006). However, The Prison Department of Malaysia will provide the necessary facilities for the inmates. Although these facilities may not be comprehensive, inmates will still be able to study well. The examples of the academic programs provided by the Prisons Department of Malaysia are :

a) $3 \mathrm{M}$ remedial classes (basic literacy classes for reading, writing and arithmetic).

b) Pre-PMR classes (lower secondary, 13-14 years old) isEF?

c) PMR classes (Lower Certificate of Education, 15 years old) is:ep:

d) Pre-SPM classes (upper secondary, 15-16 years old) issp:

e) SPM classes (equivalent to GCE O level) is:Pe?

f) STPM classes (equivalent to GCE A Level) SSEP:

g) Diploma / degree classes (for long distance education programs). isipep:

Until 20th April, 2013, there are 2,010 juvenile delinquents in a Malaysian Prison Institution. The statistics of the juvenile delinquency keeps on changing every day because of a number of factors. This due to the fact that the juvenile delinquents are faced with court cases, so either they are waiting for trial or are undergoing punishment. The imprisonment is different among the 


\section{INTERNATIONAL JOURNAL OF ACADEMIC RESEARCH IN PROGRESSIVE EDUCATION AND}

DEVELOPMENT

Vol. 7, No. 3, July 2018, E-ISSN: 2226-6348 @ 2018 HRMARS

delinquencies based on the type of offense committed. The existence of the academic classes indirectly encourages young prisoners to use the prison library to obtain information related to their education. The young prisoners in Malaysia are entitled to the same educational opportunities in life that anyone else would expect. They gain formal education and will be allowed to sit for public examinations under a special program under the Ministry of Education, in collaboration with the Prisons Department. The importance of education is emphasized to them in order to prevent them from relapsing into criminal activities. Teachers are sent to prison to teach the young prisoners, aged 21 years and below.

According to Marbley and Ferguson (1999), they found that the correctional system has not been successful in its mission of reforming or creating a rehabilitation mentality of inmates. The impact of mission failure to inmates will not prevent former inmates turning away from crime. According to Sanggaran (2008), there are a number of former inmates who have been released; however, were sent back into prison as a result that they were ill-equipped to enter the job market in Malaysia. Often, they do not possess relevant skills which could be used to earn a living. Sanggaran also found out that in Thailand, after a computer training programme was conducted at Bangkhen Women's Prison many former inmates were employed in jobs that require computer skills. Because of the prison populations throughout the world are characterized by lower than average levels of literacy, the inmates are likely to be poverty and limited employment opportunities that lead some individuals into criminal activity (Dike \& Ajogwu, 2007).

According to Rafedzi and Abrizah (2014), a major factor of re-entering the prison of juvenile delinquents is due to the failure to avoid being influenced by their old friends. One of our research participant, Mr SPO; the prison officer (2013); claimed that compared to the juvenile delinquents who are involved in activity related to drugs, are more likely to re-enter the prison compared to other juvenile offenders. Their peers who live near their residential areas and known to be their 'drug friendship' is the only barrier for them to be drug-free individuals. To some extent, this has answered why the percentage of juvenile delinquents who re-enter the prison is increasing year by year. There are 417 cases (12.4\%) of juvenile delinquents who are reentering the prison for several cases. In addition, in 2013, there were 371 cases that clearly indicate that there are several factors in the failure recovery system of juvenile delinquents (Jabatan Penjara Malaysia, 2013).

Although the Prisons Department in Malaysia has organized a number of religious education classes and to assist in the rehabilitation of juvenile delinquents, the programs still fail to help rehabilitate them before being released. The recovery process is not only subjected to educational and religious programs, but understanding patterns among their information needs and the use of prison library also need to be refined and improved.

Case (2012, mentioned that information need is a recognition that your knowledge is inadequate to satisfy a goal that you have. Each individual's needs are formed by the actual situation and by the way the individual defines that situation (Shoham \& Strauss, 2007). Furthermore, according to Campbell (2000), information needs can be defined as the perception of a lack of information that provokes one to then develop a need for it. Prisoners are regarded as disadvantaged people 
Vol. 7, No. 3, July 2018, E-ISSN: 2226-6348 @ 2018 HRMARS

because they lack free access to many things in a free society, including libraries (Lehmann, 2000). The value of the prison library cannot be underestimated (Bowe, 2011). She found that between 80 and 90 percent of the prison population use the prison library to discover reading for the first time and as the purpose to get out of their cell. Vaccarino and Comrie (2010) added that, today the prison libraries are seen as a key element in raising literacy levels and supporting prisoner education programmes which are ultimately aimed at rehabilitation and reintegration.

\section{Objective and Method}

The objective of this study is to explore how the prison information environment supports the information needs of the male juvenile delinquents in correctional schools in Malaysia. The researchers are committed to getting closer to the samples being observed in their natural setting and also looks at the book collection prepared for juvenile prisoners which will help them in their rehabilitation and education process. This method is useful in looking and finding out the needs and interests of the existing collections in their prison libraries. The field researcher would observe what is going on in the field, logging the minute detail of every aspect of tribal life; daily routines, the preparing of foods, details of the care of the body, conversations and social life (Grimshaw, 2001). The researchers' observation at all research sites has led to conclude that the prison library does not play that much roles in addressing the participants' information needs. The following findings demonstrate the need for a well-thought-out library sources and services, especially if the prison libraries are committed to serve the educational, informational, recreational and rehabilitational information needs of these young inmates.

The study involved only a few participants from a population of 2,010 (until 20 th April 2013) male juvenile delinquents at the correctional schools, Malaysian Prison Department. The number of male juveniles listed here excludes the number of male juvenile delinquents in private juvenile rehabilitation centers. In line with the UNESCO slogan "Education for All", the Ministry of Education established the Integrity Schools in 2008 for juvenile delinquents with the aim to provide education and skills to juvenile offenders, regardless of the crimes they had committed. The five (5) correctional schools sampled in this study are presented in Table 1.1.

Table 1.1 : Correctional schools in Malaysia

\begin{tabular}{|c|l|c|l|}
\hline No & \multicolumn{1}{|c|}{ Zone } & Code & \multicolumn{1}{c|}{ Location } \\
\hline 1 & Northern zone & NO & Sungai Petani, Kedah \\
\hline 2 & Central zone & CO & Kajang, Selangor \\
\hline 3 & Central Southern zone & CSO & Telok Mas, Melaka \\
\hline 4 & Southern zone & SO & Kluang, Johor \\
\hline 5 & East zone & EO & Marang, Terengganu \\
\hline
\end{tabular}

The participants were selected as any male juvenile delinquents who used the prison library within school session. The total number of participants involved was twenty six (26).

i) Central zone (5 participants)

ii) Northern zone (5 participants)

iii) Central Southern zone (10 participants) 
INTERNATIONAL JOURNAL OF ACADEMIC RESEARCH IN PROGRESSIVE EDUCATION AND DEVELOPMENT

Vol. 7, No. 3, July 2018, E-ISSN: 2226-6348 @ 2018 HRMARS

iv) Southern zone (3 participants)

v) Eastern zone (3 participants)

\section{Results and Discussion}

Youths enter correctional settings with a variety of interrelated academic, social, emotional, healths and behavioural needs (Vacca, 2008). But, the incarcerated persons generally have the same reading interests and information needs as individuals in the free world (Lehmann, 2000). The prevalence of unmet information needs in the prison was apparent in this research. This did not come as a surprise to the researcher, as much past work has given similar impression. Curry (2003) found that information needs among inmates were not fulfilled. With regards to information access failure, Curry (2003) discovered a general lack of success among many of her participants using libraries, and Burt (1977) and Le Donne (1977) realized that their participants appeared to lack the necessary skills to use the library resources effectively. Rafedzi and Abrizah (2016), information needs of juvenile delinquents are more likely related to their :

i- $\quad$ Academic needs and interests.

ii- $\quad$ Filling their time while in prison.

It may be tempting to assume that information seeking failure is inevitable, in a large measure due to the shortcomings on the part of the prison library itself. Apparently, it is not due to the young inmates' lack of desire to seek for information, but rather, the prison institutions provide inappropriate choices of sources. Undermining the ignorance of the prison authority also limits the information seeking options to the inmates, and the approaches are most likely to be effective when finding information. There were instances of what may be termed as "source and user dislocation" (Pickard 2004) where adult intervention disrupted the youth's efforts to seek for information.

The research findings in this study are not surprising. The research participants expressed their displeasure with a library and a collection of reading material. The prison library is open only during school sessions; from 8 am until $1.30 \mathrm{pm}$. On Saturdays and Sundays, the library will be closed as there is no library staff to manage the library. During the school hours, teachers were assigned to manage the prison library.

\section{Access to the library}

According to Lodal and Ra (2011) described that space requirements in prison libraries are very similar to those for other types of libraries. The premises must be inviting and designed for library functions, with hours and location convenient for the user (p. 485). According to the Integrity Schools and Henry Gurney Schools rules, the library can only be used during school hours. Which means, the library service hours are from 08.00 am until $13.30 \mathrm{pm}$ only. After school session, male juvenile delinquents will be attending prison activities such as religious classes and additional classes (for those taking national examinations). Rules are made as the institution itself has a shortage of prison staff to monitor the movement of the male juvenile delinquents in the library if the library is open until evening or at night. Library access depends on the internal operation of the facility, as well as the availability of staff and the organization of staff assignments, 
INTERNATIONAL JOURNAL OF ACADEMIC RESEARCH IN PROGRESSIVE EDUCATION AND DEVELOPMENT

Vol. 7, No. 3, July 2018, E-ISSN: 2226-6348 @ 2018 HRMARS

including the responsibility for library operations and the promotions of reading activities (Zybert, 2011).

"We open only for a few hours, there are some problems incurred by them. For example, juvenile delinquents who are not interested in using library facilities such as reading or studying; will use the library as a place to send their message that is written in secret code and put it into the book sheets. And some secret code they are written up at the book sheets! We don't know what is all about." (Mrs 2, 27 July 2013)

"Those who fully used the library, they will not create any problems. In fact, they are diligently packing the books and creating a poster to decorate the library." (Mrs 2, 27 July 2013)

\section{The prison library houses books that were limited, irrelevant and outdated resources}

Shirley (2003) listed several collections of items that should not be allowed in a prison library, such as a true crime story with inmate's photographs, bombs, disguises, karate or self-defense materials, pornography, and nude photographs. As expected, none of the libraries that were observed had materials on these topics. All of the prison libraries, house collections of reference books and textbooks for national examinations, and teenage and family novels. All libraries have many reference works on religion, such as the Al-Quran, its translation, stories of the prophets, biographies and memoirs of national personalities, and self-motivational magazine and pamphlets. According to Sullivan (2008), religion and religious reading help to reform the character of inmates and have contributed to a number of redemptions. Prisoners have admitted to have a dire need for information that could give them spiritual and emotional stability to be in good terms with God and men and become better citizens in the society (Eze, 2014). However, there are limited titles of children's story books, dictionaries and encyclopedias. Based on the portal Books to Prisoners (www.bookstoprisoners.net), the highly requested books for prisoners in 2014 are dictionaries, thesauruses, any books on starting or running business, and trade books.

In this study, the researchers' inspection of the bookshelves confirmed that many books are outdated, especially the collections of reference books and textbooks for the national examination, which were out of current syllabus. There were practically no academic books suitable for those pursuing their bachelor and diploma degree, as well as books for technical or vocational classes. Ajogwu (2005) (as cited in Eze, 2014), stated that prisoners' need information ranging from legal, religious, health, education, vocational and recreation to finance. The prison library can develop collections that include a broad range of materials for self-help, selfeducation, community resources, housing, job availability, and vocational training opportunities (Shirley, 2006). By having this type of information, it will encourage the inmates to make full use of the prison library.

The researcher had the opportunity to see several boxes received by the prison library as gifts and donations to the prison. All the boxes have reading materials contributed either by private or government agencies. The prison management usually does not preclude any types of reading materials contributed by these agencies. Typically, the materials are sorted out before they are 


\section{INTERNATIONAL JOURNAL OF ACADEMIC RESEARCH IN PROGRESSIVE EDUCATION AND DEVELOPMENT}

Vol. 7, No. 3, July 2018, E-ISSN: 2226-6348 @ 2018 HRMARS

placed in the library. The researcher found these materials are mostly outdated, irrelevant, and the contents are not useful for the current information needs of the juvenile delinquents. The teachers indicated that they were aware of the presence of the books, however, they said that they did not comment or act upon it, because of the prison authority had consented to accept the donations of the materials.

\section{The prison library does not provide a resource person}

The researcher earlier observation notes, as well as the one below, clearly show the absence of a resource person for the inmates to refer to when they are in the library. The resource person can be a library media specialist who plans and team teaches with subject teachers and integrates reading and information skills programs into the classroom curriculum. Literature indicates that it is possible for library media specialists to realize their potential as resource persons who coplan and implement instruction in collaboration with teachers (McGiffin, 1990). A peer support group is extremely valuable for self-directed educational growth and rehabilitational development among the young inmates and the presence of a resource person may facilitate this process. The following excerpts demonstrate the important role played by the library media specialist in assisting young inmates, searching for information.

\section{(SO, 28 January 2013, 11.00am to $12.04 \mathrm{pm})$}

A female Malay language teacher directs her three students into the library. She instructs them to find any information on general issues in Malaysia; from any newspapers, magazine and books. She tells them that all the information would be used for quizzes and short essays. The boys listen without asking any questions, and after about three minutes, they move to the bookshelves and look for the relevant materials. Initially, their attention is only on the books that are available on the bookshelves. They browse the shelves and when each has book in hand, they sit at the nearest table and begin to flip the book page by page. After a while, they seem not interested with the materials and they appear to be restless. All three of them stop looking at the books. SO3 stands up and goes to the teacher who is standing at the library counter. He says something to her, perhaps telling her that he is not able to get anything relevant to the topic. The teacher goes to the bookshelves, checks around and tells SO3 something. SO3 nod his head and he quickly goes to SO1 and SO2. The teacher goes back to the counter. After a while, they go to the big wooden cabinet in the corner of the library. They open the cabinet and release some old newspapers and bring them to the table. They start looking for the information and appear concentrating, and at times the following utterances are heard: "Can this be?" "Can I choose this?" and sometimes it seems like they are discussing with each other.

\section{(CSO, 6 September 2012, 09.45am to 10.30am)}

A group of four (4) students entered the library accompanied by a male teacher. The teacher followed them to the library. The teacher was talking to the prison staff, who was on duty in the prison library. He then left from the library. The four (4) students walk to the bookshelves. They were looking for something. After 10 minutes, the students decided one of them asked the prison staff. The prison staff was aware of their behaviors and 
INTERNATIONAL JOURNAL OF ACADEMIC RESEARCH IN PROGRESSIVE EDUCATION AND DEVELOPMENT

Vol. 7, No. 3, July 2018, E-ISSN: 2226-6348 @ 2018 HRMARS

admonished them. The four students kept silent and immediately went to the bookshelves. Suddenly, one of the students approach the researcher. He slowly whispers to the researcher as "Cikgu.. cikgu." The researcher looked at the prison staff and admitted that he was not aware of it. One of the students asked "What is the meaning of a personal book?" The researcher looked at the prison staff and went towards the student. The prison staff approached the researcher and the researcher explained to the students about the books they were looking for. We work together to search for the book without problems or restrictions from the prison staff. After the book was found, the students continue to sit at the library desks and they looked happy. Before they left the library, they thank the researcher.

Prison staff intervention in the information seeking process inhibited or curtailed library usage The prison authority comprises personnel's such as the prison officers, prison staffs, and warden. It is common for juvenile delinquents to be scared of prison officials as most of them have strict and fierce look, which work well while intimidating inmates; but there are others who are easy going and friendly. Based on earlier observation notes, as well as the one below, the young inmates uncomfortable with the close presence of the prison staff in the library. Encouragement from prison staffs is very important for the male juvenile delinquents to comfortably use the library collection.

\section{(CO, 23 January $2013,9.15 a m$ to $9.53 a m)$}

After choosing the reading materials, the 3 (three) boys take a sit on the clean concrete floor in the aisle between the bookshelves. They sit close to each other. [Researcher's notes: I am not sure why they act in such a way; the library is not that cold as the air conditioner has just been turned on]. I notice that the boys habitually look at the prison officer rather than having their eyes on their books. There appear some other inmates who are not interested in choosing books, but had to find one to be read.

\section{Prison rules}

Prison, the controlled environment that is filled of rules and law. Such rules include, administration and management of correctional schools and prison libraries. Correctional school was guarded by the prison staff. Each two or three classes will be guarded by prison staffs outside of the classes. This is because to control the movement of juvenile delinquents and also to look after the safety of teachers in the correctional schools. The library also has its own rules and regulations. Apart from the library basic rules, the prison library has other basic rules like the library operation hours (only in school session), juvenile delinquents are not allowed to enter the library unless they are accompanied by prison staff or teachers and juvenile delinquents are not allowed to wear shoes while in the library. Stationery is also not allowed in the library. Each movement of juvenile delinquents will be monitored by the prison staff.

(CSO, 5 September 2012, 9.00am to 10.30am) 


\section{DEVELOPMENT}

Vol. 7, No. 3, July 2018, E-ISSN: 2226-6348 @ 2018 HRMARS

CSO6 enter the library with his three (3) friends. They went straight to the bookshelves. After a moment, CSO6 stepped to the reference table. He sits back and then snorted. CSO6 seemed bored with his surroundings. His grunt has attracted the attention of prison staff that was on duty. He was reprimanded by the prison staff with a high voice. Immediately after that, he continued to accessing books at bookshelves and for the researcher; he looks like pretending to look for the book. But he was not.

(NO, 23 April 2013, 08.55am to 9.23am)

NO1 enter the library with his two (2) friends. The students went straight to the reference desk without any intentions of doing something. They just sat and looking around the library for almost 5 minutes. They were approached by the prison staff. The researcher believes that the students were not aware the presence of the prison staff. The prison staff reprimanded them with a strict voice. The researcher was not so sure about their conversation. After being 'reprimanded' by the prison staff, the two of them woke up and went to the bookshelves. The researcher observed the students' dissatisfaction or upset with the prison staff. Yes, they selected at random books and not because of their interest. After selecting a book, they return to the table and keep looking at the prison staff. They were not reading, and the book was used to protect themselves from being reprimanded by the prison staff. They flipped the pages of the book slowly. At 09.23am, the students went out of the library.

The similar situations can be seen in other prison libraries. The researcher has identified the similar behavior pattern of male juvenile delinquents while in the library. Prison staff are too sensitive of their movements, may be because of the presence of the researcher in the library. The juvenile delinquents seem quite bored with the situation that urge them to get reading material, though the reading materials are not so exciting for them to read.

\section{They are not interested with information that is not relevant to them.}

Based on life in the round theory by Chatman (1999), she found that the barriers between small worlds and the practice of normative behaviors cause information poverty among inmates. She found the following characteristics among people in a small world: (a) they always think that they have no resources available to them; (b) they are influenced by outsiders with privileged access to information; (c) their information poverty is determined by self-protective mechanisms which are used in response to social norms; and (d) their new knowledge is selectively introduced into the information world. Chatman found that people will not search for information if there is no need to do so. If members of a social world choose to ignore information, it is because their world is working without it. In other words, they will not cross the boundaries of their world to seek information.

The researchers had chances to talk with a group of three (3) research participants who were looking at magazines at the desk.

The researcher: "Do you know what happened to Sabah for the last 3 months?" 
Vol. 7, No. 3, July 2018, E-ISSN: 2226-6348 @ 2018 HRMARS

$\mathrm{CO} 2 \quad$ : "Yes. I know. Its about Sulu vs our army." .

The researcher:"Yes.. then?"

CO1 : "mmm. Sorry. We knew the story. We heard it from prison officers. But, nothing we can do about it. We have lots of problems in here."

$\mathrm{CO3} \quad$ : "No need to think about it. I know it happened at my hometown. If I was a soldier, then.. I will fight until my last breathe. I hate Sulu. But.. what can I do? I'm in here. The most challenging issues here is.. how to get cigarettes and to know who is in charge or is on duty today."

$\mathrm{CO} 2 \quad$ : "How can we think about outside issues when we have lots of problem in here?"

The important issues for male juvenile delinquents are about their life in the prison and their families (Rafedzi \& Abrizah, 2014). Issues related to the outside world are not popular with them. This situation indirectly discourages the provision of reference materials to them. There were some participants who seemed to stop themselves to receive any information from outside after being sentenced by the court. Normally, these individuals show less interest in entering the library or attending any academic class in prison.

CO1 agreed with the situation. He said that he was once to be just like that at the beginning of his entourage into prison. The nature exists as a result of being scared in prison; whether they are scared with the environment of prison, the prison officer or at the senior inmates in the prison. These fears and anxiety had lead to accuracy of Chatman's theory that people will not seek information if they do not have to. Their priority information is only for their life in prison.

\section{Prison library as place of silent communication}

It was surprising that prison as place of silent communication it is not known by the prison staffs. The researcher has been told by a teacher at Central Southern Zone when the researcher noticed a strange behavior of one of the research participants. The prison library was not only used by juvenile delinquents as place of reading, place of doing their homework, to borrow a book and for group discussion; furthermore, the library is also a place of silence communication between juvenile delinquent (or maybe a group of juvenile delinquents) with another juvenile delinquent without being noticed by prison staffs and teachers.

(CSO, 4 February 2013, 10.40am to 11.08am)

CSO15 entered the prison with four (4) other juvenile delinquents. They are going to the bookshelves on the side of the library.[The researcher only observed them from the reference table and waiting for new research finding from them]. After a moment, two (2) of them, sitting at the reference table and holding a book. They just hold the book without reading it. The other two (2) of them went to the other bookshelves in the middle of the library. And the other one (1) juvenile delinquent stay at the bookshelves on the side of the library. [The researcher saw two (2) of them who sat at the reference table were watching the movement of the library teacher. After a moment, the researcher can clearly see the movement of a juvenile delinquent at the side of the library (CSO15)]. CSO15 was like being rearranged the books on the shelves. He was quite fast arranged the books and 
Vol. 7, No. 3, July 2018, E-ISSN: 2226-6348 @ 2018 HRMARS

the researcher feels strange with his behavior. After that, two (2) of the juvenile delinquents who were in the middle bookshelves, walked out from the library and followed by CSO15. After five (5) minutes, two (2) others were out from the library after putting the books on the bookshelves.

Immediately after they left, the researchers then approached at the bookshelves. The arrangement of the books on the shelves was changed; some of the books were laid down and some are kept away. To get clear the answers, the researcher approached Mrs2. Mrs2 smiled and then told the researcher while rearranging back the books.

"This is the way they deliver their messages to their friends. Luckily, you realize it. I do not understand what is the meaning of the book arrangement. I have asked my students before this. They said, it is just a secret communication between $A$ and his best friend, B. Nobody knows what is all about. Prison staffs did not know about this. It is ok. What I can do, is rearrange back the books. So that.. the message will not send to the other juvenile delinquents."

This situation is similar to what the researcher has heard before at the Central location. The message will be put in the book and the message is in a secret code. CO1 informed that, not all things can be said in the prison. Those who said about sensitive issues, maybe reprimanded by the prison staffs. The secret code sometimes helps their friends facing problems in the prison. It is not possible that with these activities, the prison authority has been reluctant to allow the prison library to open from morning until night. The movement of juvenile delinquents in the library should also be fully monitored to avoid unwanted things to happen.

\section{Conclusion}

Juvenile delinquents are the youngest group of inmates and they still have opportunities to improve their life to be better persons. The prison library plays an important role in rebuilding the spirit and in providing education, knowledge, and spiritual guidance to juvenile delinquents in order for them to start a new life when they are released. It should aspire to assist prisoners in achieving the goals of "maintaining contact with the outside world, in some cases rehabilitating inmates, enhancing vocational skills, enabling re-entry into the community after parole, providing recreational reading during incarceration, and encouraging lifelong learning" (Conrad, 2012). Otherwise, the ethical ideals of library policies come into question, which could have negative implications for the field of prison librarianship. With these points in mind, prison libraries hope to serve juvenile delinquents' information needs must ensure the inmates' rights to read and be able to provide access to information of use to their clients. Malcolm X, who frequently used the library during his imprisonment in Norfolk remarked, ' $A$ book can change a man' (Malcom X \& Haley, 1987). This famous quote illustrates the importance of books in prison. The prison library is part of treatment facilities and should provide supplemental materials for inmates, whether for their rehabilitation, education or training processes (Lemon, 1997). It is of utmost importance that the information needs of inmates be met. If one believes in library service, one must believe that everyone should have the opportunity for it, including inmates. 
INTERNATIONAL JOURNAL OF ACADEMIC RESEARCH IN PROGRESSIVE EDUCATION AND DEVELOPMENT

Vol. 7, No. 3, July 2018, E-ISSN: 2226-6348 @ 2018 HRMARS

There should be special conviction that the young prisoners of correctional schools be provided with the best possible information sources and services. The barriers to use the library, should be solved by the prison administration. The main constraint to the future use of the prison library management among male juvenile delinquents need to be refined. In their free times, especially after school hours or during school holidays; they should be allowed to take turns using the library. Collection of material needs to be upgraded to increase their interest in reading and to appreciate the function and role of the library. The male juvenile delinquents need to be trained to stay alert to the worldwide issues happened outside of prisons as the information can help them when being released at one day.

As aptly put by Burt (1977), "those on the "inside" now will be on the "outside" soon (p. 36), signifying that very means of assuring that the juvenile delinquents return to the society as good citizens should be utilized. It is hoped that by visiting prison library, it will create new habits for male juvenile delinquents after being released. The reading habit and the lots of library services provided by libraries outside prison, may help in preventing them from back into crime they have committed a long time ago. At least, they can avoid by getting mixed up with their old friends and re-engage with crimes.

\section{References}

Ajogwu, M. N. (2005). The role of NGO's in providing library and information services to two disadvantaged groups in Nigeria. Retrieved on March, 10, 2014 from http://www.unn.edu.ng/publication s/files/The $\quad \% 20$ Role\%20of\% 20Non\%20 Governmental\%20Organizations\%20NGO. pdf

Asher, C. (2006). Interlibrary loan outreach to a prison : Access inside. Document Delivery and Electronic Reserve, 16 (3), 27-33.

Bowe, C. (2011). Recent trends in UK prison libraries. Library Trends, 59, 3, 427 - 445.

Burt, L. N. (1977). Information needs of inmates. Library Trends, 26 (1), 27-38.

Case, D.O. (ed.) (2012). Looking for information : a survey of research on information seeking, needs and behavior. 3rd. ed. Bingley : Emerald.

Campbell, D. K. (2006). The context of the information behavior of prison inmates. Progressive Librarian. Retrieved on December 23, 2010 from http://www.libr.org/ pl/26_Campbell.html.

Chatman, E. A. (1999). A theory of life in the round. Retrieved on January 23, 2011 from http://citeseerx.ist.psu.edu/viewdoc/summary?doi=10.1.1.83.4478

Conrad, S. (2012). Collection development and circulation policies in prison libraries:

An Exploratory survey of librarians in US correctional institutions. The Library Quarterly, 82 (4), $407-427$. 
INTERNATIONAL JOURNAL OF ACADEMIC RESEARCH IN PROGRESSIVE EDUCATION AND DEVELOPMENT

Vol. 7, No. 3, July 2018, E-ISSN: 2226-6348 @ 2018 HRMARS

Curry, A. (2003). Canadian federal prison libraries : A national survey. Journal of Librarianship and Information Science, 35 (3), 1 - 39.

Department of Statistic Malaysia (2016). Siaran akhbar : Statistik kanak-kanak Malaysia 2016. Retrieved on January 16, 2017 from https://www.statistics.gov.my/dosm/index.php? $r=$ column/pdfPrev\&id=UCtXbzBXUDU1N1BFSW9qUmUxS3dNUT09

Dike, V. W., \& Ajogwu, M. (2007). The role of prison libraries in promoting literacy for reformation, rehabilitation and restoration of inmates in two Nigerian prisons. Retrieved on December 20, 2010 from http://www.unn.edu.ng/publications/files/The\% 20Role\%20of\%20Prison\%20Libraries\%20in\%20Promoting\%20Literacy.pdf

Eze, J. U. (2014). Information needs of prisoners in Southeast Nigerian prisons. http://idv.sagepub.com/content/early/2014/06/16/0266666914538042

Farik Zolkepli. (2015). Malaysian youth who joined Syrian Al Qaeda terror cell detained at KLIA. Retrieved on December 12, 2015 from http://www.thestar.com.my /news/nation/2015/12/11/malaysian-youth-al-qaeda-detained-klia/

Grimshaw, A. (2001). The ethnographers eye: Ways of seeing in modern anthropology. Cambridge : Cambridge University Press.

Hasan Bahrom, Dr. (2004). Remaja, kemiskinan dan juvana suatu realiti? Seminar antarabangsa nilai dalam komuniti pasca modenisma (SIVIC 2004). Hotel City Bayview Langkawi, Kedah. 4-6 September 2004.

Jabatan Penjara Malaysia. (2013). Jumlah juvana sabitan dan reman yang ditempatkan di setiap penjara di Malaysia sehingga 20 April 2013 (berumur 21 tahun ke bawah). Unpublished report. Kajang : Jabatan Penjara Malaysia.

Lehmann, V. (2000). The prison library : A vital link to education, rehabilitation and recreation. Education Libraries, 24, 1, 5-10.

Lemon, M. (1997). Prison libraries change lives. Information Outlook. Retrieved on August 2, 2009 from http://findarticles.com/p/articles/ mi_mOFWE /is_n11_v1/ai_20078332/pg_2/?tag=content

LeDonne, M. (1977). Survey of library and informational problems in correctional facilities : A retrospective review. Library Trends, $53-70$.

Ljodal, H. K. \& Ra, E. (2011). Prison libraries the Scandinavian Way : An overview of the development and operation of prison library services. Library Trends, 59 (3), 473489. 
INTERNATIONAL JOURNAL OF ACADEMIC RESEARCH IN PROGRESSIVE EDUCATION AND DEVELOPMENT

Vol. 7, No. 3, July 2018, E-ISSN: 2226-6348 @ 2018 HRMARS

Malaysia. Ministry of Internal Affairs (2000). Prisons act 1995 : Prison regulations 2000 (amendment 2003). Retrieved on April 6, 2011 from http://www.prison.gov.my/portal/page/portal/english/undang2_en

Malcolm X, \& Haley, A. (1987). The autobiography of Malcolm X. Retrieved on December 14,2012, from http://www.goodreads.com/author/ quotes/17435.Malcolm_X

Marbley, A. F., \& Ferguson, R. (1999). Correctional systems : Rethinking the notion of education in rehabilitation. Retrieved on July 16, 2007 from http://eric.ed.gov /ERICDocs/data/ericdocs2sql/content_storage_01/0000019b/80/17/69/9f.pdf 16 July 2007

McGiffin, P.A. (1990). The school library media specialist as resource person : A descriptive study. Retrieved on March 4, 2013 from http://scholarworks.umass.edu/dissertations/AAI9110185

Pickard, A. (2004). Young people and the Internet. Library + Information Update, 3 (1), $32-4$.

Rafedzi, E.R.K. \& Abrizah, A. (2014). Information needs of male juvenile delinquents : the needs to be met in aprison setting. Information Development, 1 - 16.

Rafedzi, E.R.K. \& Abrizah, A. (2016). The challenges in making library services accessible to incarcerated male juveniles in five correctional schools. Malaysian Journal of Library \& Information Science, 21 (2), 95 - 110.

Sanggaran, S. (2008). E-skills training: Learning tech behind prison walls. Retrieved on July 12, 2009 from http://www.prihatinmalaysia.org/html/nst/150608.html

Shirley, G. L. (2003). Correctional libraries, library standards and diversity. Journal of Correctional Education, 54 (2). Retrieved on June 8, 2009 from http://findarticles.com /p/articles/mi_qa4111/is_200306/ai_n9296955.

Shirley. G. L. (2006). Prison libraries help inmates get over the fence : reducing barriers to reentry. Retrieved on February 4, 2013 from http://www.ala.org/ala/aboutala/offices/olos/incarcerated-exoffenders/btw08.cfm.

Shoham, S., \& Strauss, S. K. (2007). Information needs of North American immigrants to Israel. Journal of Information : Communication \& Ethics in Society, 5, 2/3, 185-205.

Sullivan, L. E. (2008). "Prison is dull today" : Prison libraries and the irony of pious reading. Retrieved on July 31, 2014 from http://www.jstor.org/stable/25501891 
INTERNATIONAL JOURNAL OF ACADEMIC RESEARCH IN PROGRESSIVE EDUCATION AND DEVELOPMENT

Vol. 7, No. 3, July 2018, E-ISSN: 2226-6348 ㄷ 2018 HRMARS

Vacca, J. S. (2008). Crime can be prevented if schools teach juvenile offenders to read. Children and Youth Review, 30 (9), 1055-1062.

Vaccarino, F., \& Comrie, M. (2010). Pathway to rehabilitation - prisoners' use o a public library. The Australian Library Journal, 170 - 179.

Zybert, E. B. (2011). Prison libraries in Poland : Partners in rehabilitation, culture and education. Library Trends, 59 (3), 409-426. 